\title{
Bioassay on banana rhizome discs for selecting bacteria antagonistic to Fusarium oxysporum f. sp. cubense
}

\section{Bioensaio em discos de rizomas de bananeiras para a seleção de bactérias antagonistas a Fusarium oxysporum f. sp. cubense}

\author{
Liliane Santana Luquine'; Luciano Ricardo Braga Pinheiro²; Saulo Alves Santos de \\ Oliveira $^{3}$; Harllen Sandro Alves Silva ${ }^{4 *}$
}

\section{Highlights:}

Banana rhizome discs were used to select bacteria antagonistic to $F$. oxysporum f. sp. cubense. ImageTool software was used for disc evaluation.

Cluster analysis was adopted to group the most efficient antagonists.

Three antagonists provided 53 to $56 \%$ reduction in pathogen colonization.

\begin{abstract}
Detached plant organs are alternative materials to in vitro tests for selecting biocontrol agents. On the other hand, the use of scales to quantify injured areas can generate inconsistent results. Rhizospheric and endophytic bacteria were selected as growth inhibitors of Fusarium oxysporum f. sp. cubense (Foc), the causal agent of Panama disease of banana. For this, rhizome discs were treated with $200 \mu \mathrm{L}$ of antagonist suspension $\left(10^{9} \mathrm{CFU} \mathrm{mL} \mathrm{mL}^{-1}\right)$ and inoculated with the pathogen. The material was placed in plastic gerbox boxes and incubated in BOD at $25^{\circ} \mathrm{C}$ for 12 days. Afterward, the area of rhizome discs $\left(\mathrm{mm}^{2}\right)$ colonized by Foc was quantified by digital images. The assay was set up in a completely randomized design, with four replications and three discs per replication. The control consisted of untreated and inoculated discs. The results showed the efficiency of this method in selecting the biological control agent, as the 26 isolates were group into five different clusters, with isolates belonging to four of these groups (from ' 1 ' to ' 4 ') being able to reduce Foc colonization. Isolates 520EB, 993EB, and 531EB had the highest potential for inhibition, with areas of $343.3,344.1,364.8 \mathrm{~mm}^{2}$, respectively, promoting inhibition ranging from 53 to $56 \%$ of the colonized area compared to the control $\left(782.6 \mathrm{~mm}^{2}\right)$.
\end{abstract}

Key words: Panama disease. Musa spp. Biological control.

\section{Resumo}

O emprego de órgãos vegetais destacados é uma alternativa aos testes in vitro para seleção de agentes de biocontrole. Por outro lado, o uso de escalas para quantificação de área lesionada pode gerar resultados inconsistentes. Bactérias rizosféricas e endofíticas foram selecionadas como inibidoras do crescimento

${ }^{1} \mathrm{Dr}^{\mathrm{a}}$, Empresa Brasileira de Pesquisa Agropecuária, EMBRAPA Mandioca e Fruticultura, Cruz das Almas, BA, Brasil. E-mail: lilianeluquine@yahoo.com.br

2 Analista, Laboratório de Microbiologia do Solo e Resíduos Orgânicos, EMBRAPA Mandioca e Fruticultura, Cruz das Almas, BA, Brasil. E-mail: luciano.braga@embrapa.br

3 Pesquisador, Laboratório de Fitopatologia, EMBRAPA Mandioca e Fruticultura, Cruz das Almas, BA, Brasil. E-mail: saulo. oliveira@embrapa.br

4 Pesquisador, Laboratório de Microbiologia do Solo e Resíduos Orgânicos, EMBRAPA Mandioca e Fruticultura, Cruz das Almas, BA, Brasil. E-mail: harllen.alves@embrapa.br

* Author for correspondence 
de Fusarium oxysporum f. sp. cubense (Foc), agente causal do mal-do-Panamá da bananeira. Para tanto, discos de rizoma foram tratados com $200 \mu \mathrm{L}$ de suspensão dos antagonistas $\left(10^{9} \mathrm{UFC} \mathrm{mL}^{-1}\right)$ e inoculados com patógeno. $\mathrm{O}$ material foi disposto em caixas plásticas tipo gerbox e incubado em BOD a $25^{\circ} \mathrm{C}$, por doze dias. Após, a área dos discos de rizoma $\left(\mathrm{mm}^{2}\right)$ colonizada por Foc dos discos foi quantificada por meio de imagens digitais. O ensaio foi montado em delineamento inteiramente casualizado, com quatro repetições e três discos por repetição. Discos não tratados e inoculados compuseram o controle. Com base nos resultados obtidos, foi possível verificar a eficiência do método na seleção de agente de controle biológico, uma vez que foi possível o agrupamento dos 26 isolados utilizados em cinco clústeres distintos, sendo que isolados pertencentes a quatro destes grupos (do ' 1 ' a ' 4 ') foram capazes de proporcionar a redução da colonização por Foc. Os isolados com maior potencial de inibição foram $520 \mathrm{~EB}, 993 \mathrm{~EB}$ e $531 \mathrm{~EB}$ com $343,3,344,1,364,8 \mathrm{~mm}^{2}$, respectivamente, promovendo inibição variando de 53 a $56 \%$ da área colonizada quando comparados com ao controle $\left(782,6 \mathrm{~mm}^{2}\right)$.

Palavras-chave: Mal-do-Panamá. Musa spp. Controle biológico.

Banana is one of the most consumed and produced fruits in Brazil, placing it as the world's fifth-largest producer (Food and Agriculture Organization of the United Nations [FAOSTAT/FAO], 2018). However, banana production can be compromised by a large number of phytodiseases, such as Panama disease, caused by the fungus Fusarium oxysporum f. sp. cubense (E. F. Smith) Snyder and Hansen (1953). Considered one of the most destructive, this disease causes high losses, being a limiting factor to cultivate varieties appreciated in the market, such as the 'Maçã' banana (Cordeiro, Matos, \& Meissner, 2004).

Strategies to control Panama disease include the use of resistant varieties because there is no chemical control to date. However, the genetic improvement of banana is considered complex and time-consuming due to crop characteristics. Therefore, alternative measures, such as the use of biological control agents, have been studied to minimize losses caused by this disease.

A large number of studies have been carried out with beneficial microorganisms, such as rhizobacteria and endophytic bacteria, aiming at improving the field performance of seedlings, which can be used to increase agricultural production as plant growth promoters and disease biocontrol agents.

Lian et al. (2009) observed that endophytic bacteria isolated from healthy banana trees reduced
Panama disease symptoms by $67 \%$ and promoted growth of micropropagated seedlings. Idris, Labuschagne and Korsten (2007) used rhizobacteria to control root rot in sorghum, caused by Fusarium oxysporum, via soil treatment. Benchimol, Chu, Yuitimuto and Dias (2000) tested the effect of endophytic bacteria isolated from black pepper seedlings in reducing mortality caused by fusariosis, a disease caused by the fungus Fusarium solani, and found that Methylobacterium radiotolerans controlled the pathogen, causing a significant reduction in the number of dead plants.

According to Chen, Mei, Liu and Kloepper (1996), around $2 \%$ of cultivable microorganisms provide some beneficial effects when associated with vegetables. Based on this assumption, the search for antagonists to phytopathogens should begin with a significant number of isolates to increase the chances of success after the selection stage.

Selecting potential biocontrol agents is usually carried out from hundreds of isolates, in a relatively simplified way, through in vitro assays under conditions that favor the antagonist (Zheng et al., 2011; Silva, Tozzi, Terrasan, \& Bettiol, 2012). Although this technique allows the identification of antagonists that inhibit the growth of pathogens by the production of antimicrobial compounds or hyperparasitism, other biocontrol mechanisms, such as competition and systemic resistance induction, can be underestimated (Knudsen et al., 1997). 
Moreover, ecological factors related to the antagonist, such as the ability to survive under different conditions of humidity, temperature, soil type, and others that can affect the performance of the biocontrol agent, have been neglected (Fravel, 2005). Some authors have related the nonreproducibility in the field of the results obtained from laboratory tests with these factors (Fiddaman, O’Neill, \& Rossall, 2000; Szandala \& Backhouse, 2001; Rajkumar, Lee, \& Lee, 2005; Spadaro \& Gullino, 2005; Eljounaidi, Lee, \& Bae, 2016). In this case, the selection process under laboratory conditions, by ignoring the interactions with the plant species and environmental fluctuations to which microorganisms will be exposed, often overestimates the antagonist performance.

On the other hand, the use of selection methods in the field, or even in the greenhouse, where factors related to the natural cultivation environment are covered to a greater extent, may be unfeasible from the operational and economic point of view due to the demand for space and labor when working on a large number of isolates. This limitation is especially decisive when it comes to perennial crops.

The greater attention paid in the last two decades to ecological factors involved in antagonistpathogen-host interactions, together with the study of biocontrol mechanisms, has led to changes in the selection processes of biological control agents. Thus, the use of detached plant tissues has been a widely used technique to overcome difficulties already reported when working with plants for selecting antagonists. Several studies have used, for instance, leaf discs, detached leaves, and petal discs (Zhang, Zhou, Li, Fu, \& Wang, 2017; H. S. A. Silva et al., 2012; Burmeister \& Hau, 2009; Shiomi, Silva, Melo, Nunes, \& Bettiol, 2006; Rajkumar et al., 2005; Fiddaman et al., 2000).

Considering that Fusarium oxysporum f. sp. cubense infects vascularized areas of the banana rhizome (Ploetz, 2015), the use of these tissues as an auxiliary technique for the selection of antagonists to the pathogen is a hypothesis to be tested as a support to the program for the biocontrol of Panama disease. Thus, defining a method for the inoculation of $F$. oxysporum f. sp. cubense and evaluating the antagonism of selected bacteria in in vitro assays to the pathogen, on banana rhizome discs, were the objectives of the study.

In both assays, rhizomes originating from 'Maçã' banana plants showing good phytosanitary aspects and grown under field conditions were scalped and cut into discs of $7 \mathrm{~cm}$ in diameter and $1 \mathrm{~cm}$ thick. They were then submitted to treatment with alcohol $(50 \%)$ for 1 minute, followed by sodium hypochlorite ( $2 \%$ ) for 1 minute and three rinses with sterile distilled water. Disinfected discs were placed in plastic boxes $(11 \times 11 \times 3.5$ $\mathrm{cm})$, containing filter paper moistened with sterile water.

Fusarium oxysporum f. sp. cubense (Foc) race 1 was isolated from symptomatic banana trees, included in the collection of crops of the Laboratory of Phytopathology of Embrapa Cassava \& Fruits

Two methods of pathogen inoculation (suspension of conidia and mycelium discs) were evaluated in banana rhizome discs of varieties 'Maçã' and 'Prata Anã'. Pathogen propagules used in the assay were obtained from 10-day Foc colonies grown on potato dextrose agar (PDA) at $25{ }^{\circ} \mathrm{C}$ under fluorescent light. Mycelium discs of $0.7 \mathrm{~cm}$ in diameter were deposited on the center of rhizome discs under aseptic conditions. The conidia suspension was adjusted to $10^{4}$ conidia $\mathrm{mL}^{-1}$ by applying a volume of $200 \mu \mathrm{L}$ to each rhizome disc.

The assay was set up in a completely randomized design in a $2 \times 2$ factorial scheme (inoculation methods $\times$ varieties), with ten replications per treatment. The control consisted of rhizome discs on which sterile distilled water and a culture medium disc without fungal growth were applied. Rhizome discs were evaluated after 10 days for the area colonized by the pathogen, as described. The data were subjected to analysis of variance and 
the means compared by the F-test at $5 \%$ using the SISVAR statistical program.

The inhibition of Foc colonization in banana rhizome discs treated with antagonistic bacteria was verified according to the inoculation method selected in the previous assay and taking into account the variety and method that provided the largest significant area colonized by the pathogen.

Twenty-six bacterial isolates, among rhizobacteria and endophytic bacteria, from rhizospheric soil and banana plant tissue samples, respectively, belonging to the Active Germplasm Bank of Embrapa Cassava \& Fruits, selected in in vitro tests by Luquine (2012) regarding the ability to inhibit Foc growth by the production of diffusible antimicrobial compounds in culture medium (Romeiro, 2007), volatile antimicrobial compounds (Bharat, Singh, \& Singh, 1980), and chitinase (Renwick, Campbell, \& Coe, 1991), were evaluated in this assay.

The entire procedure was performed in a laminar flow chamber. Initially, $200 \mu \mathrm{L}$ bacterial suspension was applied to the center of discs, prepared from colonies with $24 \mathrm{~h}$ growth at $25{ }^{\circ} \mathrm{C}$ in agar nutrient medium in sterile distilled water. The concentration of each suspension was adjusted to $\mathrm{OD}_{540}=0.5$,

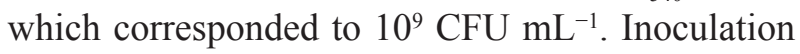
was carried out $48 \mathrm{~h}$ after the application of bacterial isolates by depositing a Foc mycelium disc with spores $(0.7 \mathrm{~cm}$ in diameter), obtained from a culture grown at $25{ }^{\circ} \mathrm{C}$ for ten days, on the center of each rhizome disc.

The assay was set up in a completely randomized design with four replications per antagonist, with each replication consisting of three discs. Untreated and non-inoculated discs, as well as discs inoculated with Foc alone, were used as control. Discs were maintained in BOD with a 12-hour photoperiod at $25{ }^{\circ} \mathrm{C}$. Daily observations were carried out to verify mycelial growth and the presence of lesions on the discs.

After 12 days, the discs were photographed with a digital camera and the colonized area was measured using the software ImageTool v.3.0 (UTHSCSA, University of Texas Health Science Center, San Antonio). The data were submitted to analysis of variance and hierarchical clustering of means by Ward's method based on the Euclidean distance between samples. Box-plot analyses were performed to compare the bacteria based on their origin (endophytic or rhizospheric) and biocontrol mechanisms previously evaluated by Luquine (2012), possibly involved in the interaction with Foc. The analyses were performed using the statistical program R (R Core Development Team, 2017).

The obtained data showed that Fusarium oxysporum f. sp. cubense (Foc) inoculation using mycelium discs on rhizome discs had a better performance from the point of view of substrate colonization compared to the method with the suspension of conidia in the 'Maçã' variety (Table 1). Although there was pathogen colonization on the rhizome disc, no difference was observed between inoculation methods in the 'Prata Anã' variety. No fungal growth was observed on non-inoculated rhizome discs.

The difference between fungal structures evaluated in the test, as well as the used plant tissue, should be taken into account to explain the results. Initially considering the pathogen, Foc conidia are reproductive structures that require favorable environmental and nutritional conditions for germination to occur, as well as macroconidia and chlamydospores (Beyer, Röding, Ludewig, \& Verreet, 2004). Although rhizome discs were maintained under conditions of high humidity and ideal temperature for Foc, the possible scarcity of nutrients available in the plant tissue may have significantly affected the induction of conidia germination. Thus, fewer germinated conidia led to the presence of a few infectious structures of the pathogen and, therefore, a small-colonized area compared to treatment with mycelium discs.

A significant interaction was observed between cultivars and inoculation methods. The mycelium 
disc method had a colonized area larger in the 'Maçã' cultivar, but the same when using conidia suspension. On the other hand, 'Prata Anã' showed no difference between colonized areas regarding both inoculation methods.

\section{Table 1}

Colonization of banana rhizome discs by Fusarium oxysporum f. sp. cubense inoculated using a suspension of conidia and mycelium discs

\begin{tabular}{crc}
\hline \multirow{2}{*}{ Cultivar } & \multicolumn{2}{c}{ Treatment } \\
\cline { 2 - 3 } & Mycelium discs $^{\mathrm{a}}$ & Conidia suspension \\
\hline 'Prata Anã' & $1231.6 \mathrm{aB}^{\mathrm{b}}$ & $972.4 \mathrm{aA}$ \\
'Maçã' & $1544.4 \mathrm{aA}$ & $1070.5 \mathrm{bA}$ \\
\hline CV $(\%)^{\mathrm{c}}$ & & 17.89 \\
\hline
\end{tabular}

${ }^{\mathrm{a}}$ Colonized area in $\mathrm{mm}^{2}$.

${ }^{b}$ Means followed by the same uppercase letter in the column and lowercase letter in the row do not differ significantly from each other by the F-test at $5 \%$ probability.

${ }^{\mathrm{c}}$ Coefficient of variation.

The comparison between varieties showed the highest values of the colonized area by the pathogen in rhizomes for the 'Maçã' variety when using the mycelium disc method. This result was already expected, as this variety is highly susceptible to the pathogen compared to 'Prata Anã', considered moderately susceptible or tolerant.

According to Beckman (1990), Foc infects the roots of susceptible and resistant banana cultivars, but the colonization of the vascular system in the rhizome is more evident in susceptible varieties. It is in line with the results of the assay with mycelium discs, which showed low rhizome colonization in the 'Prata Anã' variety, which is moderately susceptible, even with the direct contact of the pathogen with the plant tissue unprotected from natural barriers.

Regarding mycelium discs, in addition to the fungal structure already formed on the rhizome, nutrients contained in the cultivation discs with colonies may have guaranteed survival of the fungus, providing better conditions for the pathogen to establish in the plant tissue. Although possibly affected by the effects of the action of phenolic compounds and tissue oxidation, the presence of fungal mycelium and its ability to penetrate the tissues actively, as well as the presented results, support a high probability of success when inoculating Foc using mycelium discs on banana rhizome discs.

Thus, the choice of the method of Foc inoculation on banana rhizome discs using mycelium discs was effective in allowing the infection and colonization of the plant tissue by the pathogen and the visualization and quantification of symptoms. Given its ease of working, this method was used in a later trial instead of conidia suspension. Thus, it is proposed that this method of inoculation be adopted, regardless of the used banana variety, although the degree of susceptibility to the pathogen is taken into account.

The inhibition of Foc colonization on rhizome discs treated with antagonistic bacteria allowed the 26 isolates to be divided into five groups, of which 21 significantly reduced the area colonized by the pathogen in four different groups, according to clusters in Figure 1. Among the three isolates with the best performance, the colonized disc areas were $343.31,344.05$, and $364.78 \mathrm{~mm}^{2}$ for the antagonists 520EB, 993EB, and 531EB, respectively. Disc colonization by the fungus was reduced by about 
$400 \mathrm{~mm}^{2}$ in these treatments, i.e., more than $50 \%$ compared to the control $\left(782.6 \mathrm{~mm}^{2}\right)$ (Figure 1).

Also, the three best performing antagonists (520EB, 993EB, and 531EB) have an endophytic origin (Figure 1). According to Ramamoorthy, Viswanathan, Raguchander, Prakasam and Samiyappan (2001), endophytic bacteria colonize more efficiently the same ecological niches of phytopathogens, especially vascular pathogens. This characteristic can favor their action and increase the chances of successful biocontrol, as verified in the assay. The success of studies involving endophytic bacteria and biological control of vascular pathogens is reported by Eljounaidi et al. (2016).

The three biocontrol mechanisms evaluated for the selection of antagonists, i.e., the production of volatile and diffusible antimicrobial compounds and chitinase, are characteristics of the three best performing isolates. It is in line with the strategy of searching for different ways of microorganisms acting to increase the chances of success in selecting antagonists to phytopathogens. Furthermore, it allows the use of combined isolates as long as there is no inter-inhibition.

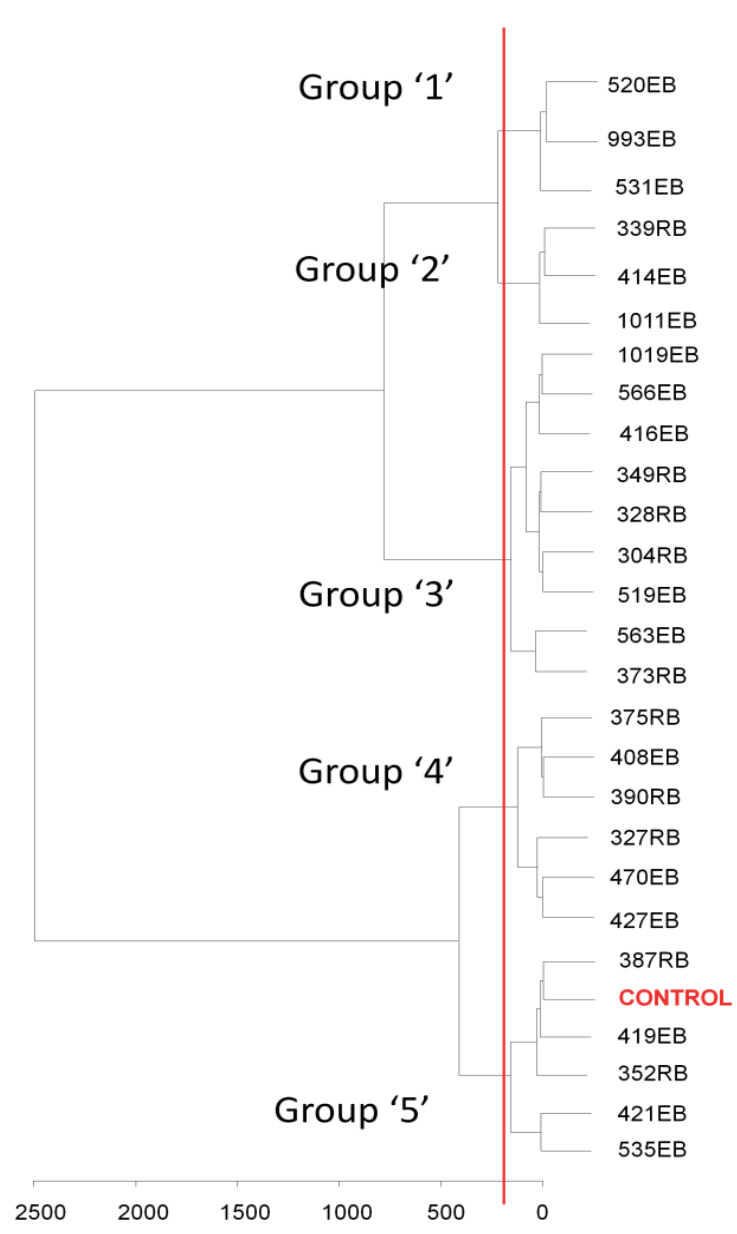

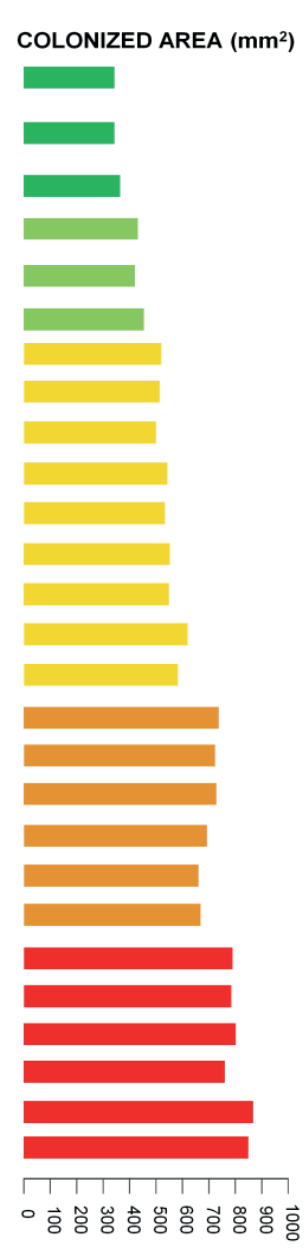

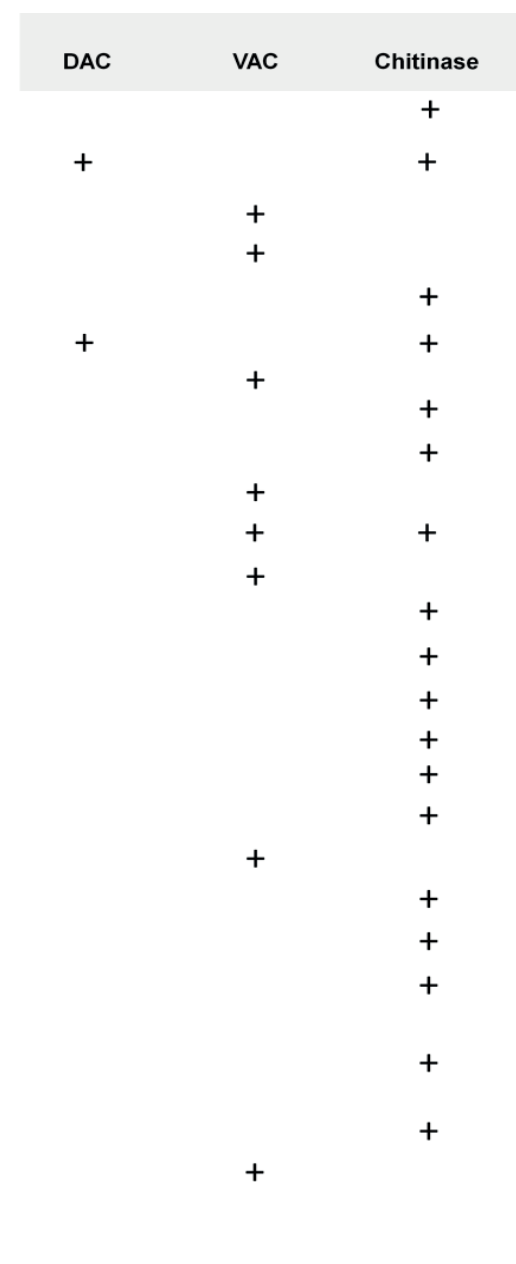

Figure 1. Cluster analysis of 26 bacterial isolates. The bar graph expresses the values of area colonized $\left(\mathrm{mm}^{2}\right)$ by Fusarium oxysporum f. sp. cubense on banana rhizome discs of the 'Maçã' variety treated with a suspension of antagonistic bacteria and subsequently inoculated with mycelial discs of Foc. On the right is the biocontrol mechanisms inherent to each antagonist under study (Luquine, 2012). CAD - diffusible antimicrobial compounds; VAC - volatile antimicrobial compounds. Rhizobacteria - numeric code followed by RB; endophytic bacteria - numeric code followed by "EB." 
Although the three isolates with the best biocontrol potential come from endophytic colonization, there was no significant difference between the means of colonization reduction compared to those obtained for the tested rhizobacteria isolates (Figure
2A). Similarly, a significant difference was found between isolates when they were grouped according to the type of mechanism involved in the biocontrol (Figure 2B).
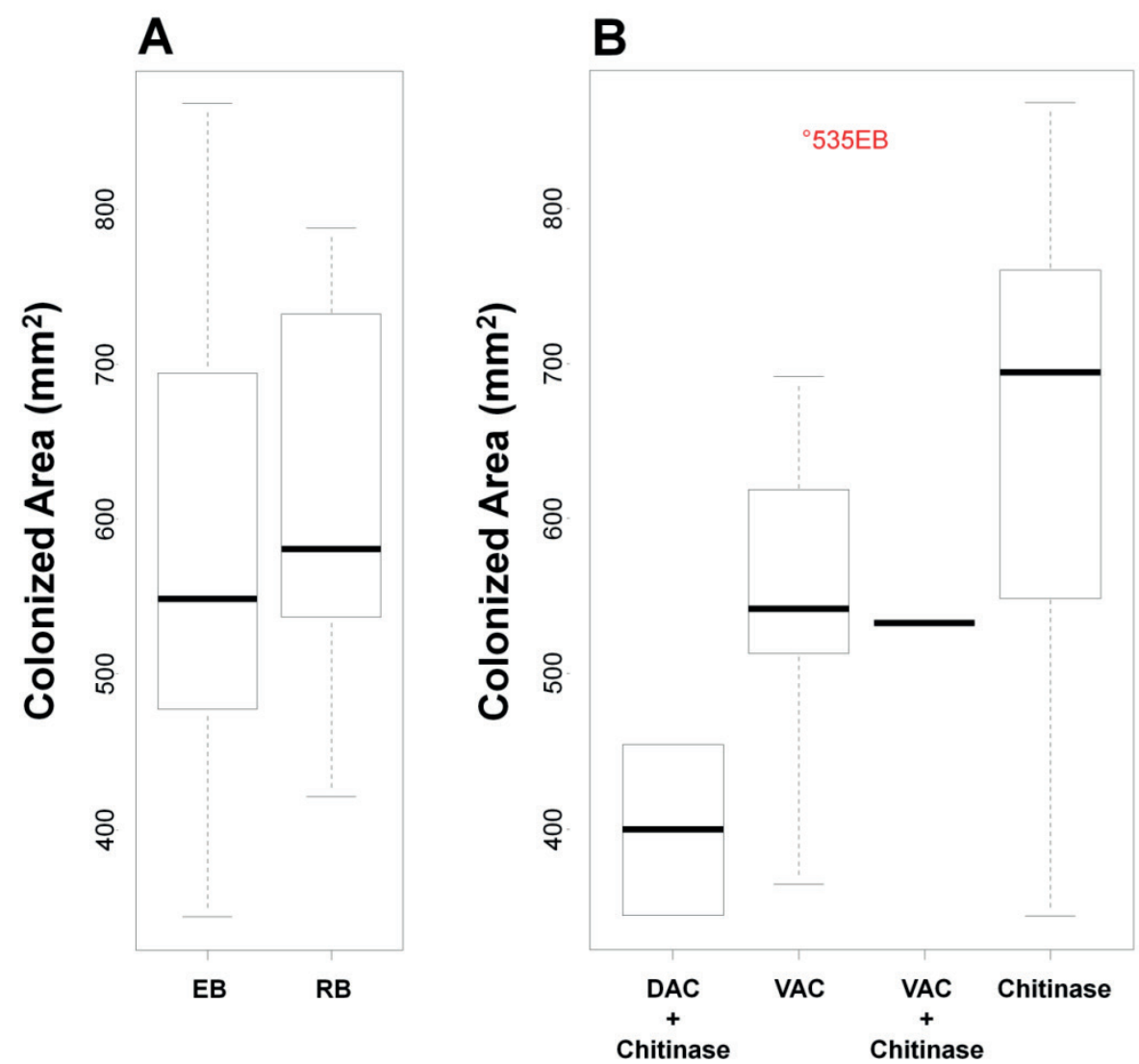

Figure 2. Box-plot of values obtained for the colonized area of different treatments $\mathrm{A}$ ) according to the origin of isolates (endophytic bacteria = 'EB' and rhizobacteria $=$ 'RB') and B) according to the type of mechanism used for the biocontrol of Fusarium oxysporum f. sp. cubense (DAC: diffusible antimicrobial compounds; VAC: volatile antimicrobial compounds or chitinase production).

Several isolates selected for the same biocontrol mechanism provided different levels of Foc inhibition (Figure 2). The assays for the production of antimicrobial compounds were qualitative. Thus, bacteria with lower performance, some even under control, may synthesize compounds under concentrations that do not significantly inhibit the pathogen, as observed for the 535EB isolate. In this case, the 535EB isolate showed no inhibition to the pathogen, with a colonized area higher than $800 \mathrm{~mm}^{2}$, while the average colonized area of VAC producers was approximately $520 \mathrm{~mm}^{2}$. It may be one of the causes of inconsistent results of biocontrol agents in the field or even under greenhouse conditions.

Selecting phytopathogen biocontrol agents is not a simple task due to the diversity of microorganisms 
or interactions with the host plant. One of the key pieces to increase the chances of reaching the desired objectives are the assays with a large number of potential antagonists interacting against the pathogen on a laboratory scale. For this purpose, the used methods must be effective in the selection of antagonistic characteristics of low cost and culminate in obtaining isolates that can be produced on a large scale, with consistent results in the field.

Thus, antagonist selection methods should involve, whenever possible, ecological and environmental factors, such as interaction with the host, temperature, humidity, $\mathrm{pH}$, among others (Fiddaman et al., 2000; Spadaro \& Gullino, 2005). Thus, besides the direct inhibition of the pathogen by compounds, the competition and survival capacity of the agent will also be evaluated, as well as indirect forms of control involving the induction of systemic resistance.

Bioassays involving detached plant organs appear for this purpose, i.e., to avoid the artificiality of in vitro selection methods, but keeping the cost relatively low and the possibility of working with a large number of potential antagonists. Köhl, Postma, Nicot, Ruocco and Blum (2011) postulate that the basic requirement for this type of study is the presence of the host or its tissues under controlled and epidemiologically representative conditions.

There are a large number of studies involving the selection of phytopathogen biocontrol agents using plant tissues such as leaf discs, detached leaves and flowers, and petal discs (Zhang et al., 2017; H. S. A. Silva et al., 2012; Burmeister \& Hau, 2009; Rajkumar et al., 2005; Szandala \& Backhouse, 2001; Shiomi et al., 2006; Helbig, 2001; Fiddaman et al., 2000). In the rhizome disc assay, besides the antagonist-pathogen confrontation under a condition that involves tissues colonizable by both, there is the possibility of studies involving different levels of temperature and humidity, thus expanding the range of situations to which both biocontrol agents and Foc are submitted.
The use of banana rhizome discs in the selection tests of biocontrol agents for Panama disease is a method that presents all the desired advantages, such as low cost, reduced physical space, and time spent, in addition to verifying the performance of the antagonist on host tissues. Based on the strategy of combining in vitro selection results with those obtained on rhizome discs, there is a great chance of success of biocontrol when carried out in the field. Considering infected rhizomes as the most efficient way of spreading Foc (Ploetz, 2015), this tissue becomes a perfect material to verify the effectiveness of an antagonist in controlling that phytopathogen.

Luquine (2012) confirmed the antagonistic action of bacteria 993EB, 304RB, and 416EB (selected in the present study using the presented methodology) to Foc on banana plants in a greenhouse. The antagonists, applied in combination of isolates, reduced disease severity by 55 and $45 \%$ for varieties 'Prata Anã' and 'Maçã', respectively.

However, there is the possibility of mismatched performance of biocontrol agents in the greenhouse and/or field, selected under controlled conditions in vitro, or even by other methods involving plant tissues. Assays selecting potential biocontrol agents usually involve a large number of candidates, and under natural cultivation conditions, there are several climate and biological variables involved, which are unlikely to be fully controlled.

According to Fravel (2005), although many agents have been isolated and selected through in vitro inhibition assays over the years, results obtained in the laboratory have not been verified in a large number of field researches. The most important causes of this discrepancy are the high level of control of environmental factors in the selection of agents in the laboratory and the absence of interaction with the host plant.

Combined with the methodology involving the use of rhizome discs, the technique of using digital images to evaluate the results proved to be a very 
accurate tool, as it has high reliability due to the storage of information and allows error checking when necessary, different from the traditional scale evaluation, in which the evaluator may influence.

Silva, Oliveira and Haddad. (2011) used photographs of detached plant parts of cassava inoculated with Fusarium sp. to evaluate the level of resistance to root rot in different accessions. The analysis of the material by digital photography was efficient for separating genotypes at different levels of resistance to the pathogen and can be used in breeding programs for preliminary evaluation of the tested material.

\section{Conclusions}

The method of inoculating Fusarium oxysporum f. sp. cubense on banana rhizome discs colonized by rhizospheric and endophytic antagonistic bacteria, followed by the digital image analysis to quantify the area damaged by fungus, can be used to assist studies aiming at the selection of Fusarium oxysporum f. sp. cubense.

\section{References}

Beckman, C. H. (1990). Host responses to the pathogen. In R. C. Ploetz (Ed.), Fusarium wilt of banana (pp. 93105). St. Paul, MN: The American Phytopathological Society.

Benchimol, R. L., Chu, E. Y., Yuitimuto, R., \& Dias, M. B., Fo. (2000). Controle da fusariose em plantas de pimenta-do-reino com bactérias endofíticas: sobrevivência e respostas morfofisiológicas. Pesquisa Agropecuária Brasileira, 35(7), 1343-348.

Beyer, M., Röding, S., Ludewig,A., \& Verreet, J.-A. (2004). Germination and survival of Fusarium graminearum macroconidia as affected by environmental factors. Journal of Phytopathology, 152(2), 92-97. doi: 10.1111/j.1439-0434.2003.00807.x

Bharat, R., Singh, V. N., \& Singh, D. B. (1980). Trichoderma viride as a mycoparasite of Aspergillus spp. Plant and Soil, 57(1), 131-135.

Burmeister, L., \& Hau, B. (2009). Control of the bean rust fungus Uromyces appendiculatus by means of Trichoderma harzianum: leaf disc assays on the antibiotic effect of spore suspensions and culture filtrates. BioControl, 54(4), 575-585. doi: 10.1007/ s10526-008-9202-9

Chen, Y., Mei, R., Liu, L., \& Kloepper, J. W. (1996). The use of yield increasing bacteria (YIB) as plant growth-promoting rhizobacteria in Chinese agriculture. In R. S. Utkhede, \& V. K. Gupta (Eds.), Management of soil born diseases (pp. 165-184). Ludhiana: Kalyani Publishers.

Cordeiro, Z. J. M., Matos, A. P., \& Meissner, P. E., F ${ }^{\circ}$. (2004). Doenças e métodos de controle. In A. L. Borges, \& L. S. Souza (Eds.), O cultivo da bananeira (pp. 146-182). Cruz das Almas, BA: EMBRAPA Mandioca e Fruticultura.

Eljounaidi, K., Lee, S. K., \& Bae, H. (2016). Bacterial endophytes as potential biocontrol agents of vascular wilt diseases - review and future prospects. Biological Control, 103, 62-68. doi: 10.1016/j. biocontrol. 2016.07.013

Food and Agriculture Organization of the United Nations (2018). Production crops. Recuperado de http:// faostat.fao.org/site/339/default.aspx

Fiddaman, P. J., O’Neill, T. M., \& Rossall, S. (2000). Screening of bacteria for the suppression of Botrytis cinerea and Rhizoctonia solani on lettuce (Lactuca sativa) using leaf disc bioassays. Annals of Applied Biology, 137(3), 223-235.

Fravel, D. R. (2005). Commercialization and implementation of biocontrol. Annual Review of Phytopathology, 43, 337-359. doi: 10.1146/annurev. phyto.43.032904.092924

Helbig, J. (2001). Biological control of Botrytis cinerea Pers. ex Fr. in strawberry by Paenibacillus polymyxa (Isolate 18191). Journal of Phytopathology, 149(5), 265-273. doi: 10.1046/j.1439-0434.2001.00609.x

Idris, H. A., Labuschagne, N., \& Korsten, L. (2007). Screening rhizobacteria for biological control of Fusarium root and crown rot of sorghum in Ethiopia. Biological Control, 40 (1), 97-106. doi: 10.1016/ j.biocontrol.2006.07.017

Knudsen, I. M. B., Hockenhull, J., Funk Jensen, D., Gerhardson, B., Hökeberg, M., Tahvonen, R., Teperi, R., Sundheim, L., \& Henriksen, B. (1997) Selection of biological control agents for controlling soil and seed-borne diseases in field. European Journal of Plant Pathology, 103(9), 775-784.

Köhl, J., Postma, J., Nicot, P., Ruocco, M., \& Blum, B. (2011). Stepwise screening of microorganisms for commercial use in biological control of plant- 
pathogenic fungi and bacteria. Biological Control, 57(1), 1-12. doi: 10.1016/j.biocontrol.2010.12.004

Lian, J., Wang, Z., Cao, L., Tan, H., Inderbitzin, P., Jiang, Z., \& Zhou, S. (2009). Artificial inoculation of banana tissue culture plantlets with indigenous endophytes originally derived from native banana plants. Biological Control, 51(3), 427-434. doi: 10.1016/j.biocontrol.2009.08.002

Luquine, L. S. (2012). Aplicação conjunta de rizobactérias e bactérias endofiticas para o biocontrole do Maldo-panamá da bananeira. Dissertação de mestrado, Universidade Federal do Recôncavo da Bahia, Cruz das Almas, BA, Brasil.

Ploetz, R. C. (2015). Fusarium wilt of banana. Phytopathology, 105(12), 1512-1521. doi: 10.1094/ PHYTO-04-15-0101-RVW

Rajkumar, M., Lee, W. U., \& Lee, K. J. (2005). Screening of bacterial antagonists for biological control of Phytophthora blight of pepper. Journal of Basic Microbiology, 45(1), 55-63. doi: 10.1002/jobm. 200410445

Ramamoorthy, V., Viswanathan, R., Raguchander, T., Prakasam, V., \& Samiyappan, R. (2001). Induction of systemic resistance by plant growth promoting rhizobacteria in crop plants against pests and diseases. Crop Protection, 20(1), 1-11.

R Core Development Team (2017). R: A Language and Environment for Statistical Computing. Retrieved from http://www.R-project.org

Renwick, A., Campbell, R., \& Coe, S. (1991). Assessment of in vitro screening systems for potential biocontrol agents of Gaeumannomyces graminis. Plant Pathology, 40(4), 524-532. doi: 10.1111/j.13653059.1991.tb02415.x

Romeiro, R. S. (2007). Controle biológico de enfermidades de plantas: procedimentos. Viçosa, MG: Ed. UFV.
Shiomi, H. F., Silva, H. S. A., Melo, I. S., Nunes, F. V., \& Bettiol, W. (2006). Bioprospecting endophytic bacteria for biological control of coffee leaf rust. Scientia Agricola, 63(1), p. 32-39. doi: 10.1590/ S0103-90162006000100006

Silva, H. S. A., Tozzi, J. P. L., Terrasan, C. R. F., \& Bettiol, W. (2012). Endophytic microrganismos from coffee tissues as plant growth promoters and bicontrol agents of coffee leaf rust. Biological Control, 63, 6267. doi: 10.1016/j.biocontrol.2012.06.005

Silva, H. S. A., Oliveira, S. A. S., \& Haddad, F. (2011). Uso de imagens digitalizadas em metodologias de seleção para resistência à podridão radicular de mandioca. (Boletim de Pesquisa e Desenvolvimento, 54). Cruz das Almas, BA: EMBRAPA Mandioca e Fruticultura Recuperado de http://www.cnpmf. embrapa.br/publicacoes/boletins/boletim_54.pdf

Snyder, W. C. \& Hansen, H. N. (1953). Species concept, genetics, and pathogenicity in Hypomyces solani. Phytopathology, 44(2), 338-342.

Spadaro, D., \& Gullino, M. L. (2005). Improving the efficacy of biocontrol agents against soilborne pathogens. Crop Protection, 24(7), 601-613. doi: 10.1016/j.cropro.2004.11.003

Szandala, E. S., \& Backhouse, D. (2001). Suppression of sporulation of Botrytis cinerea by antagonists applied after infection. Australasian Plant Pathology, 30(2), $165-170$.

Zhang, X., Zhou, Y., Li, Y., Fu, X., \& Wang, Q. (2017). Screening and characterization of endophytic Bacillus for biocontrol of grapevine downy mildew. Crop Protection, 96, 173-179. doi: 10.1016/ j. cropro.2017.02.018

Zheng, Y., Xue, Q.-Y., Xu, L.-L., Xu, Q., Lu, S., Gu, C., \& Guo, J.-H. (2011). A screening strategy of fungal biocontrol agents towards Verticillium wilt cotton. Biological Control, 56, 209-2016. doi: 10.1016/j. biocontrol.2010.11.010 